UDC 35.088 .6

D. Nelipa, Dr. Sc. (Polit.), Assoc. Prof., orcid.org/0000-0002-5363-3990,

O. Batrymenko, Dr. Sc. (Polit.), Assoc. Prof., orcid.org/0000-0003-0211-248X
DOI: $10.29202 /$ nvngu/2018-2/16

Taras Shevchenko National University of Kyiv, Kyiv, Ukraine, email: d.v.nelipa@gmail.com; oleg_batrymenko@ukr.net

\title{
STRATEGY, MANAGEMENT MODEL AND EDUCATIONAL SCIENTIFIC CIVIL SERVANTS TRAINING PROGRAM IN POSTGRADUATE STUDIES OF THE UNIVERSITY
}

Purpose. To reveal the main stages of the development of the educational and scientific program of training specialists of PhD (Doctor of Philosophy) level in the field of Public Management and Administration, on the example of the organizational work of State Governance Department of Taras Shevchenko National University of Kyiv (KNU named after T. Shevchenko).

Methodology. The results of the study were obtained through application of the following methods: analysis and synthesis in the study of strategies, programs, curricula, ratings, which allow analyzing the main directions of educational and scientific activities of the State Governance Department of Kyiv University; systematic and comparative methods that were used in determining the essence and peculiarities of training Masters of Civil Service at KNU named after T. Shevchenko.

Findings. The authors developed and implemented in the educational process of KNU named after T. Shevchenko:

1. Educational and scientific program of training specialists of level III of higher education (Doctor of Philosophy) in specialty 281 "Public Management and Administration" on the competence-based approach.

2. Disciplinary model of training curriculum for the mentioned above specialists as well as specific curriculum for postgraduate students in the given specialty.

3. The program of the academic discipline "System analysis in Public Management and Administration", which is one of the key discipline in methodology of training postgraduate students.

Originality. The author's educational and scientific program of training specialists of the $\mathrm{PhD}$ level in the specialty "Public Management and Administration" was offered. The novelty of the program is as follows:

1. The development of the philosophical component by including philosophical disciplines in the program of training civil servants. Namely, the development and implementation of the discipline "Philosophy of Science and Innovation".

2. Focus on political science training for civil servants. Development and implementation of training courses: "Geopolitical challenges of the present", "Features of the interaction of political and administrative positions in the system of public management and administration", "Foreign practice of decentralization of public authority at the local level", "Democratization of mechanisms of public management and administration in Ukraine".

3. Implementation of interdisciplinary knowledge in training civil servants in postgraduate study in the training course "Innovative Technologies in Public Management and Administration".

Practical value. The obtained results allow us to affirm that the development of the methodology for the study of educational needs of public service managers with new approaches to enhancing their professional competence is a promising direction for further training of civil servants at post-graduate course in KNU named after T. Shevchenko.

Keywords: state management, public service, educational and scientific programs, management model, public management and administration, Doctor of Philosophy, higher education

Introduction. An integral part of the sustainable state development of Ukraine is the creation and functioning of an effective system of public administration whose tasks are to ensure the rights and freedoms of citizens, and provide qualitative administrative services. Success of implementation of the separate tasks of state administration largely depends on development of the system of professional teaching of civil servants.

Modern education, as a continuous creative process of mastering new knowledge, skills and abilities, is the basis of state stability, progressive development of society and the well-being of every citizen.

One of the most important components of the professionalization of civil service and service in the local

(C) Nelipa D., Batrymenko O., 2018 self-government bodies is the organization and provision of targeted training of specialists. Taras Shevchenko National University of Kyiv (University) provides its contribution to the professionalization of the civil service of Ukraine. The University belongs to the network of educational institutions of the system of training, retraining and advanced training of civil servants and officials of local self-government bodies, as it trains masters and postgraduates in the specialty "Public Service" of the field of knowledge "Public Administration". In the article, the authors reveal the main stages of development of educational and scientific program of training specialists of $\mathrm{PhD}$ (Doctor of Philosophy) level in the field of Public Management and Administration, on the example of the organizational work of State Governance Department of Taras Shevchenko National University of Kyiv. 
Analysis of the recent research. The problem of training public managers, masters and postgraduates of the civil service in Ukraine is considered in many works. The historiography of these works is presented, for example, in books of Yu. Kovbasyuk and K. Vashchenko [1], D. Dzvinchuk and V. Malimon [2], and others. Work in this direction is coordinated by the National Academy of Public Administration under the President of Ukraine, and its regional divisions in Dnipropetrovsk, Lviv, Odesa and Kharkiv. Despite a large number of works in this range of problems, the authors expanded the scope of research and attracted works on philosophical disciplines, in particular, on the philosophy of education in specialized discussion in the field of knowledge "Public Administration".

While working on the article, the authors analyzed the research studies of O. Bazaluk [3], S. Rudenko [4], M. Salamone [5] and other scientists, thanks to whom the historical and philosophical conception of the development of theories of education in the history of culture and in Ukraine, in particular, was laid under the modern scientific and methodological basis of the study. The research conducted by I. Liashenko [6], D. Svyrydenko [7], S. Terepyshchyi [8], T. Isaacs [9], and others allowed the authors to bring the problem of governance and public administration to contemporary discourse in the Ukrainian educational landscape.

Presentation of the main research. Recognition of Taras Shevchenko National University of Kyiv as the leader of higher education in Ukraine is confirmed every time, when strategic and tactical decisions which the University makes concerning the development of educational directions, improvement of the educational process, changes in approaches to methodological and organizational provision of training of specialists, and others, after a certain period of time, receive direct or indirect (in the form of the normative documents, in which the norms or approaches have been introduced already at the University) recognition of the colleagueseducators, scientists, government officials, and employers.

University employees work in the working groups, whose scientific work is aimed at various aspects of reforming education and science. For example, the legislation on education, the national qualifications framework, the national system of qualifications, the framework of higher education qualifications, academic mobility, pilot projects of educational standards of a new type, methodical recommendations for the development of standards, new lists of directions and specialties, the development of new regulations of various kinds, and others.

Formation of student and post-graduate-centered curricula absolutely agrees with the strategy of developing the national qualifications system, with the content of employers' proposals for reforming higher education, with the recommendations of specialized European organizations, with the development strategy of education, developed by the National Academy of Pedagogical Sciences of Ukraine, and others. And, unlike many others, Taras Shevchenko National University of Kyiv departs from the "process" organization of the educational process (listened to the course - received a diploma).

Despite the unpopularity and financial costs, the University carries out all the activities which are capable to:

1. Guarantee high-quality education, attractiveness and transparency of university curricula for potential consumers.

2. Increase the level of students' satisfaction with all components of the educational process.

3. Provide public confidence in the diplomas issued by the university.

4. Contribute to the development of graduates' competences required for employment and career growth, and so forth.

In particular, for the implementation of the competence approach 495 passports of clusters/specialties were approved in the University during 2013 academic year [10].

Normative and special courses on public administration, local government, socio-political management, strategic planning, regional economy, social development management, psychology of personnel management and some more courses are included into the curricula of Departments of Philosophy, Law, Economics, Sociology, Psychology and Institutes of Journalism and International relations traditionally.

Taking into account the high need of the national system of public administration in highly skilled personnel, State Governance Department was established at the Philisophy Faculty of the University in 2011, and the training of specialists on the educational and professional program of Master degree in the specialty "Civil Service" in the direction "Public Administration" started on the full-time and extramural basis.

On July 1, 2014, the Verkhovna Rada of Ukraine adopted the Law of Ukraine "On Higher Education" [11]. The new Law provides for the introduction of a threelevel model for training specialists with higher education (Bachelor, Master, Doctor of Philosophy), as well as the application of a competent approach as the main methodological tool for the formation of educational and educational-scientific programs.

The process of implementation of the new Law of Ukraine "On Higher Education" provides for a gradual transition from the programs of the candidate of sciences in State Management training to the programs of PhD training (Doctor of Philosophy) in the field of Public Management and Administration. Before the adoption of the new Law of Ukraine "On Higher Education" the candidate of sciences training in Taras Shevchenko National University of Kyiv was conducted in three academic majors: 25.00.01 - Theory and History of State Governance; 25.00.02 - Mechanisms of State Governance; 25.00.03 - Civil Service.

In 2015, in Ukraine admission to the postgraduate course on the candidate's degree program was carried out for the last time, and in 2016 the first admission to the postgraduate course on the program for $\mathrm{PhD}$ training (Doctor of Philosophy) was carried out. 
At the time of writing the article there was no national standard of higher education of level III (Doctor of Philosophy) in specialty 281 "Public Management and Administration". Based on the experience of the authors and members of the State Governance Department of Taras Shevchenko National University of Kyiv some effective recommendations on the stated topic can be formulated and proposed for the working group of the Ministry of Education and Science of Ukraine that develop a national standard for training civil servants under the program of Doctor of Philosophy (level III of higher education).

The authors developed and implemented the following concepts in the educational process of the University:

Educational and scientific program of specialists training of level III of higher education (Doctor of Philosophy) in specialty 281 "Public Management and Administration" on the competence-based approach.

Disciplinary model of training curriculum for specialists of level III of higher education (Doctor of Philosophy) in specialty 281 "Public Management and Administration" as well as specific curriculum for postgraduate students in specialty 281 "Public Management and Administration" at Taras Shevchenko National University of Kyiv.

The program of the academic discipline "System analysis in Public Management and Administration", which is one of the key disciplines in the methodology for training a postgraduate student.

The authors created the organizational and managerial strategy for the development of training programs for civil servants of level III of higher education (Doctor of Philosophy) at Taras Shevchenko National University of Kyiv. The main ideas of the development strategy are based on retrospection to the ideas of the classics of philosophical thought, their rethinking on the basis of modern knowledge, as well as their embodiment in everyday life, taking into account the forecasts for the future. For example, views of Wilhelm Dilthey [12], Otto Friedrich Bollnow [13], Martin Heidegger [14], and others.

The organizational and managerial strategy for the development of training programs for civil servants of the third level of higher education envisages:

1. Preservation and development of the philosophical component by including philosophical disciplines in the program of civil servants training, namely, "Philosophy of Science and Innovations".

2. Focusing on the political training of civil servants. The training courses "Geopolitical Challenges of the Present", "Features of the Interaction of Political and Administrative Positions in the System of Public Management and Administration", "Foreign Practice of Decentralization of Public Authority at the Local Level", "Democratization of Mechanisms of Public Management and Administration in Ukraine" were introduced.

3. Introduction of the interdisciplinary disciplines in the civil servants training in the postgraduate course, namely, the training course "Innovative Technologies in Public Management and Administration”.
Taking into account that the overwhelming majority of students and postgraduates are government officials of the central executive authorities, the educational process is aimed not only at improving existing competencies but also at creating new career prospects for a civil servant. Just for this reason the authors developed additional recommendations for the training programs for civil servants of level III of higher education (Doctor of Philosophy) at Taras Shevchenko National University of Kyiv, which include:

1. Supporting the continuity of education of civil servants from the level of Bachelor to Doctor of Philosophy. The authors adhere to the philosophical tradition in education, which considers obtaining knowledge as a way of life. Even the achievement of the level "Doctor of Philosophy" in the field of Public Management and Administration, if one adheres to the philosophical tradition, it is only one of the temporary stages of human life, which must be followed necessarily by the next stages of obtaining knowledge and applying it in professional activities [3-5].

2. Creation of a training program for admission to the Postgraduate and Master (magistracy) studies in specialty 281 "Public Management and Administration" at the Preparatory Department of the University. I. Liashenko and S. Rudenko [6] devoted their article to work of the Preparatory Department of Taras Shevchenko National University of Kyiv, as well as to the development of a strategy for managing the Preparatory Department of the University in the philosophical tradition of Plato's line, which allows students to view knowledge as a way of life.

In developing an effective system of public administration, the authors determine the following features of the general competencies of the educational and scientific program of civil servants training of the postgraduate course in the University [15]. In addition to the typical competencies (ability to abstract thinking, analysis and synthesis, the use of information technology, and others), the emphasis is done on such competencies as:

1. Ability to work in the international scientific space.

2. Ability to communicate with non-professionals in their field (with experts from other fields).

Focusing on the leading universities of the world in the training of specialists, including the humanities and socio-economic sphere, as well as natural sciences and engineering, the University has introduced intensification of the educational process, namely, reducing the proportion of classroom activities in the total amount of study time by strengthening the role of students' selftraining activities. The consistent stimulation of the real independent work of students (postgraduate self-training) in mastering academic disciplines is a prerequisite for the graduates of postgraduate studies provided by the ISCED-2011, EQF-HE, EQF-LLL levels of responsibility and autonomy.

Limitation of the volume of classroom activities should encourage teachers, departments, and research and methodological commissions of faculties/institutes to:

1. Improve teaching and learning processes.

2. Reduce the reproductive component of teaching to the minimum necessary level sequentially. 
3. Increase demands upon students' work in extracurricular time.

4. Increase the amount of academic hours allocated for practical (extracurricular) training.

According to the results of implementation of the educational and scientific program of specialists training of level III of higher education in the field of Public Management and Administration in Taras Shevchenko National University of Kyiv, postgraduates have to acquire the following professional competencies:

1. Ability to analyze issues in the field of Public Management and Administration systematically.

2. Skills in giving professional advise in the field of Public Management and Administration.

3. Ability to recognize the contingent of students and solve problems in the learning process.

4. Ability to carry out research in the field of Public Management and Administration, taking into account the possible context of the interpretations of those or other issues or problems.

5. Competence in a number of modern training strategies.

6. Ability to regulate curricula for a specific educational context in the field of Public Management and Administration.

7. Ability to develop and implement new methodologies for research in the field of Public Management and Administration.

8. Ability to solve the problems of Public Management and Administration, to be familiar with the primary sources and normative documents.

9. Ability to develop, substantiate and apply new concepts in the research on Public Management and Administration, to classify them and to carry out a comparative analysis.

10. Ability to investigate scientifically the psychological aspects of public management and administration in the world and Ukraine, the influence of public and quasi-governmental organizations on the dynamics of socio-political processes.

11. Ability to model and optimize the systems of public management and administration taking into account the challenges and opportunities of the modern globalization processes.

12. Capacity for practical reforming of means of ensuring public management and administration in Ukraine on the basis of analysis of foreign experience and its application.

13. Ability to study and understand critically the use of information technology in the modern public-management space.

14. Ability to investigate scientifically the modern approaches to ensuring public management and administration in Ukraine, analyze independently the legislation with the aim of solving problems of public management and administration.

15. Ability to analyze critically commonly accepted concepts in public management and administration and develop their own research.

Using the world and European experience, as well as taking into account the profiles of the professional com- petence of the civil service position, the authors developed and implemented a disciplinary model of the curriculum for the civil servants training in postgraduate study. In general, all disciplines in the curriculum of the educational and scientific program on public management and administration were divided into four groups: 1) compulsory academic disciplines; 2) the discipline (elective) on the faculty/institute's option; 3) the discipline (elective) on the free choice of a post-graduate student (general university list); 4) discipline (elective) on free choice of postgraduate student (list of faculty).

1. Compulsory academic disciplines:

The $1^{\text {st }}$ year of study: Philosophy of Science and Innovation (7 ECTS).

The $2^{\text {nd }}$ year of study: English academic writing, (3 ECTS).

The $3^{\text {rd }}$ year of study: Assistant pedagogical practice (10 ECTS).

The $4^{\text {th }}$ year of study: Complex exam in specialty, dissertation work for PhD degree (Doctor of Philosophy).

2. Disciplines (elective) on the faculty/institute's option:

The $1^{\text {st }}$ year of study:

a) system Analysis in Public Management and administration (in English) (4 ECTS);

b) geopolitical challenges of the present (4 ECTS).

3 . Disciplines (elective) on the free choice of a postgraduate student general university list):

The $2^{\text {nd }}$ year of study:

a) public administration of competitiveness of the country in the conditions of globalization (4 ECTS);

b) prevention and counteraction to the corruption in the public management and administration (4 ECTS);

c) methods for providing quality of public management and administration (4 ECTS);

d) communicative provision of public management and administration (4 ECTS);

e) democratization of mechanisms of public management and administration in Ukraine (4 ECTS);

f) innovative technologies in public management and administration (4 ECTS);

g) features of co-operation of political and administrative positions in the system of public management and administration (4 ECTS);

h) the International practice of decentralization of public power at the local level (4 ECTS).

Conclusions. The professionalization of state administrators, civil service in particular, is an urgent need and an important factor in strengthening the statehood and formation of qualitatively new social relations in Ukraine. Together with other higher educational institutions, where specialists in the field of public administration are trained, Taras Shevchenko National University of Kyiv contributes to raising the level of professional competence of civil servants.

Thus, the following features should be referred to training of civil servants of level III of higher education (Ph.D.) in specialty "Civil service" in the University:

1. Combination of the best traditions of classical university education with the newest teaching methods. 
2. Formation of curriculum oriented to the needs of the present.

3. Introduction of a competence-based approach to teaching.

4. Strengthening of practical training (taking into account the profiles of professional competence of civil service positions).

5. The growth of the autonomy of studying (enhancing the role of self-training).

A promising direction for further research on this topic is, in our opinion, development of the methodology to study the learning needs of public managers with regard to new approaches to improvement of their professional competence.

\section{References.}

1. Kovbasyuk, Yu. V. and Vashchenko, K. eds., 2012. Public Administration. Volume 1. Kyiv: NAPA.

2. Dvinkuchuk, D. and Malimon, V., 2012. Introduction to Specialty: course of lectures. Ivano-Frankivsk: City of HV.

3. Bazaluk, O., 2017. Plato's and Isocrates' Traditions in the Development of Educational Theories in the History of Culture. Annals of the University of Craiova Philosophy Series, 40(2), pp. 5-18.

4. Rudenko, S., Sobolievskyi, Y. and Tytarenko, V., 2018. Cosmology in the Philosophical Education of Ukraine: History and Modern Condition. Philosophy and Cosmology, 20, pp. 128-137.

5. Salamone, M. A., 2017. Equality and Justice in Early Greek Cosmologies: The Paradigm of the "Line of the Horizon". Philosophy and Cosmology, 18, pp. 22-31.

6. Liashenko, I. and Rudenko, S., 2018. The Management Features of the University Preparatory Department. Naukovyi Visnyk Natsionalnoho Hirnychoho Universytetu, 1, pp. 163-168.

7. Svyrydenko, D., 2016. Mobility Turn in Contemporary Society as an Educational Challenge. Future $\mathrm{Hu}$ man Image, 3(6), pp. 102-108.

8. Bazaluk, O., Svyrydenko, D. and Terepyshchyi, S., 2017. Structural-Functional Models of Integration and Reintegration of Ukrainian Educational Landscape. Naukovyi Visnyk Natsionalnoho Hirnychoho Universytetu, 5, pp. 163-168.

9. Isaacs, T., 2014. Critical Agency in Educational Practice: A Modern South African Perspective. Future $\mathrm{Hu}$ man Image, 1(4), pp. 41-56.

10. Report of the rector of Taras Shevchenko National University of Kyiv for 2013 [pdf]. Available at: <http:// www.univ.kiev.ua/pdfs/Zvit2013.pdf $\quad$ [Accessed 12 April 2017].

11. Verkhovna Rada of Ukraine, 2014. Law of Ukraine "On Higher Education" dated 01.07.2014 № 1556-VII (edited as of 01.01.2018) [online]. Available at: < http:// search.ligazakon.ua/1_doc2.nsf/link1/T141556.html> [Accessed 23 September 2017].

12. Liashenko, I., 2018. Wilhelm Dilthey: Understanding the Human World. Philosophy and Cosmology, 20, pp. 177-199.

13. Bazaluk, O. and Matusevych, T., 2014. Otto Friedrich Bollnow: Search for the Fundamentals of Existen- tial Philosophy. Annals of the University of Craiova Philosophy Series, 34(2), pp. 5-16.

14. Bazaluk, O. and Nezhyva, O., 2016. Martin Heidegger and Fundamental Ontology. Annals of the University of Craiova - Philosophy Series, 38 (2), pp. 71-83. 15. Taras Shevchenko National University of Kyiv, 2017. Educational and scientific program of preparation of doctors of philosophy in specialty 281 Public administration and administration (specialization "Public administration and administration") [pdf]. Available at: <http:// philosophy.univ.kiev.ua/uploads/editor/ONP_26_06 2017/\%D0\%9E\%D1\%81\%D0\%B2\%D1\%96\%D1\%8र $\%$ D $0 \%$ B D \% D $1 \% 8$ C \% D $0 \%$ B E - \% D $0 \%$ B D $\%$ D0\% B0\% D1\%83\% D0\% BA\% D0\% BE\% D0\% B2\% D0\%B0\%20\%D0\%BF\%D1\%80\%D0\%BE\%D0\%B3\% D1\%80\%D0\%B0\%D0\%BC\%D0\%B0-281.pdf> [Accessed 5 October 2017].

16. Ursul, A. and Ursul, T., 2017. Education and Globalistics. Future Human Image, 7, pp. 136-153.

\section{Стратегія, управлінська модель та освітньо-наукова програма підготовки державних службовців в аспірантурі університету}

\section{Д. В. Неліпа, О. В. Батрименко}

Київський національний університет імені Тараса Шевченка, м. Київ, Україна, e-mail: d.v.nelipa@gmail.com; oleg_batrymenko@ukr.net

Мета. Полягає в тому, щоб розкрити основні етапи розробки освітньо-наукової програми підготовки фахівців рівня „Доктор філософії“, за спеціальністю „Публічне управління та адміністрування“, на прикладі організаційної роботи кафедри державного управління Київського національного університету імені Тараса Шевченка (КНУ ім. Т. Шевченка).

Методика. Результати дослідження отримані за рахунок застосування таких методів: аналізу й синтезу при дослідженні стратегій, програм, навчальних планів, рейтингів, що дозволяють здійснити аналіз основних напрямів навчальної й наукової діяльності кафедри державного управління Київського університету; системний і компаративний методи, що використовувалися при визначенні сутності та особливостей підготовки магістрів державної служби у КНУ ім. Т. Шевченка.

Результати. Авторами були розроблені й впроваджені в навчальний процес КНУ ім. Т. Шевченка:

1. Освітньо-наукова програма підготовки фахівців III рівня вищої освіти (Доктор філософії) за спеціальністю 281 „Публічне управління та адміністрування" на основі компетентнісного підходу.

2. Дисциплінарна модель навчального плану підготовки вищезгаданих фахівців, а також конкретний навчальний план підготовки аспірантів за даною спеціальністю.

3. Програма навчальної дисципліни „Системний аналіз у публічному управлінні та адміністру- 
ванні“, що є однією з ключових у методологічній підготовці аспірантів.

Наукова новизна. Запропонована авторська освітньо-наукова програма підготовки фахівців рівня „Доктор філософії“ за спеціальністю „Публічне управління та адміністрування“. Новизна програми полягає в наступному:

1. У розвитку філософської складової шляхом включення філософських дисциплін до програми підготовки державних службовців. А саме, розробка й впровадження дисципліни „Філософія науки та інновацій“.

2. Акцентуванні уваги на політологічній підготовці державних службовців. Розробка й впровадження навчальних курсів: „Геополітичні виклики сучасності“, „Особливості взаємодії політичних і адміністративних посад у системі публічного управління та адміністрування“, „Зарубіжна практика децентралізації публічної влади на місцевому рівні“, „Демократизація механізмів публічного управління та адміністрування в Україні““.

3. Впровадженні міждисциплінарних знань до підготовки державних службовців в аспірантурі в навчальному курсі „Інноваційні технології в публічному управлінні та адмініструванні“".

Практична значимість. Отримані результати дозволяють стверджувати, що розробка методики вивчення освітніх потреб державних управлінців 3 урахуванням нових підходів до підвищення рівня їх професійної компетентності є перспективним напрямом подальшої підготовки державних службовців в аспірантурі КНУ ім. Т. Шевченка.

Ключові слова: державне управління, державна служба, освітньо-наукові програми, управлінська модель, публічне управління та адміністрування, доктор філософії, вища освіта

\section{Стратегия, управленческая модель и образовательно-научная программа подготовки государственных служащих в аспирантуре университета}

\section{Д. В. Нелипа, О. В. Батрименко}

Киевский национальный университет имени Тараса Шевченко, г. Киев, Украина, e-mail: d.v.nelipa@gmail.com; oleg_batrymenko@ukr.net

Цель. Заключается в том, чтобы раскрыть основные этапы разработки образовательно-научной программы подготовки специалистов уровня „Доктор философии“, по специальности „Публичное управление и администрирование“, на примере организационной работы кафедры государственного управления Киевского национального университета имени Тараса Шевченко (КНУ им. Т. Шевченко).

Методика. Результаты исследования получены за счет применения таких методов: анализа и синтеза при исследовании стратегий, программ, учебных планов, рейтингов, которые позволяют осуществить анализ основных направлений учебной и научной деятельности кафедры государственного управления Киевского университета; системный и компаративный методы, которые использовались при определении сущности и особенностей подготовки магистров государственной службы в КНУ им. Т. Шевченко.

Результаты. Авторами были разработаны и внедрены в учебный процесс КНУ имени Тараса Шевченко:

1. Образовательно-научная программа подготовки специалистов III уровня высшего образования (Доктор философии) по специальности 281 „Публичное управление и администрирование“ на основе компетентностного подхода.

2. Дисциплинарная модель учебного плана подготовки вышеуказанных специалистов, а также конкретный учебный план подготовки аспирантов по данной специальности.

3. Программа учебной дисциплины „Системный анализ в публичном управлении и администрировании“, которая является одной из ключевых в методологической подготовке аспирантов.

Научная новизна. Предложена авторская образовательно-научная программа подготовки специалистов уровня „Доктор философии“ по специальности „Публичное управление и администрирование“. Новизна программы заключается в следующем:

1. В развитии философской составляющей путем включения философских дисциплин в программу подготовки государственных служащих. А именно, разработка и введение дисциплины „Философия науки и инноваций“".

2. Акцентировании внимания на политологической подготовке государственных служащих. Разработка и введение следующих учебных курсов: „Геополитические вызовы современности“, „Особенности взаимодействия политических и административных должностей в системе публичного управления и администрирования“, „Зарубежная практика децентрализации публичной власти на местном уровне“, „Демократизация механизмов публичного управления и администрирования в Украине“.

3. Введении междисциплинарных знаний в подготовку государственных служащих в аспирантуре в учебном курсе „Инновационные технологии в публичном управлении и администрировании“.

Практическая значимость. Полученные результаты позволяют утверждать, что разработка методики изучения образовательных потребностей государственных управленцев с учетом новых подходов к повышению уровня их профессиональной компетентности является перспективным направлением дальнейшей подготовки государственных служащих в аспирантуре КНУ им. Т. Шевченко.

Ключевые слова: государственное управление, государственная служба, образовательно-научные программы, управленческая модель, публичное управление и администрирование, доктор философии, высшее образование

Рекомендовано до публікації докт. наук з держ. упр. А. Савковим. Дата надходження рукопису 11.01.17. 